\title{
THE TREATMENT OF PEPTIC ULCERATION BY VAGOTOMY AND FINNEY PYLOROPLASTY
}

\author{
W. Garden Hendry, F.R.C.S., F.R.C.S.E. \\ Surgeon, Highlands General Hospital, London, N.2 I
}

IT would be generally agreed that any method of surgical treatment for peptic ulceration which preserved the stomach capacity would be superior to any form of gastrectomy, provided that recurrence of ulceration was not appreciably greater. The well-known disabilities following a percentage of gastrectomies include small-stomach syndrome, true dumping, regurgitant vomiting, weight loss, not to mention mechanical vomiting, gastro-jejuno-colic fistula, and rupture of the duodenal stump. It has, therefore, seemed obligatory to explore the possibilities of a more conservative method, which would avoid the above-mentioned disabilities, and yet have a good prospect of curing the patient of his ulcer pain. It was with this end in view that the present series was commenced and the results are now presented.

\section{Material}

The series consists of $\mathrm{I}$ I 8 cases of duodenal and gastric ulceration treated personally by the author by the method of vagotomy and Finney pyloroplasty. Cases of emergency hæmorrhage are included, but no cases of perforation are in the present series, as the author favours the conservative method of treatment, and no cases have been treated by the suture method during this time. No gastrectomy has been performed for these conditions during this period, but in 14 cases, because of a large indurated 'duodenal ulcer tumour', Finney's pyloroplasty was thought inadvisable for technical reasons and a gastrojejunostomy was substituted. These latter cases have, naturally, been excluded from the present series.

\section{Pyloroplasty versus Gastro-jejunostomy}

It has always appeared reasonable to the author that the duodenum should be preserved as a functioning unit and not converted into a cul-de$s a c$, and there seems no good reason to suggest that the duodenum is not the equal, if not the superior of the jejunum in withstanding the products of gastric digestion, once the necessary adjustments in the peptic ulcer patient have been made. It seems important that the ' $\mathrm{mix}$ ' of gastric contents with bile and pancreatic juice should take place at the accepted site, and that every effort should be made to avoid having these two important digestive juices chasing a meal down the gastro-intestinal tract. Moreover, as will be shown by the results, pyloroplasty is greatly superior to gastro-jejunostomy in the complete absence of the mechanical complications which can beset the latter operation. I refer, of course, to such conditions as bilious vomiting (nine of I Io cases, Holt et al., 1955, I I of 193 cases, Hindmarsh, I957), diffuse inflammation of the gastric mucosa from chronic jejunal regurgitation, with consequent nausea and anorexia (Weinberg et al., 1956), circus movement through the antrum with consequent hyper-secretion of acid and a tendency to nullify the vagotomy. Also to be taken into account are such serious matters as prolapse of the jejunum into the stomach, obstruction to the afferent or the efferent loop, volvulus of the stoma, prolapse of the jejunum into the lesser sac with strangulation, etc.

\section{The Choice of Pyloroplasty}

There are two classical methods of pyloroplasty:

I. Mickulicz Type. A simple longitudinal incision is made across the pyloric muscle and sewn vertically. This method was used in a number of cases at the beginning of the study, but gastric delay in emptying occurred in a few cases, demanding a conversion to a Finney operation. These converted cases are included in the series.

2. Finney Type. After approximation by suture of the second part of the duodenum to the pyloric canal of the stomach, an inverted $\mathrm{U}$-incision is made up the second part of the duodenum, across the pyloric sphincter and down the pyloric canal. The great advantage of this method is that there is no limitation to the size of the new gastro-duodenal opening, as in the Mickulicz operation, and no gastric stasis need occur. I do not wish to infer that a large opening is necessary: in practice, an opening which will admit the tip of the thumb 
seems satisfactory. But in cases with a good deal of scarring I consider that this is difficult to achieve with the more limited Mickulicz operation. If the latter procedure is used routinely, the incidence of gastric retention will be at least $4 \%$ (Weinberg et al., 1956) and this in my submission is a difficulty avoided by the use of the Finney procedure.

\section{Contra-indications to Finney Pyloroplasty}

I. Excessive œdema and thickening of the duodenal bulb. Approximation of thickened tissues may be impossible, and an adequate stoma may not be obtained.

2. Post-bulbar ulceration. The ulceration and fibrosis may be 'round the corner' down the second part of the duodenum, and so far removed from the pyloric sphincter that it would be difficult technically to incorporate both in the pyloroplasty anastomosis.

3. A dilated low-hanging stomach. In this case, a Finney pyloroplasty will be inadequate to drain the dilated atonic stomach, and a gastrojejunostomy must be used, to ensure proper emptying of the organ.

In this series there have been 14 such cases demanding the substitution of gastro-jejunostomy (an incidence of $12 \%$ ).

\section{The Rationale of Vagotomy and Pyloroplasty}

I. Duodenal Ulcer. The pathology of these cases is not always one of chronic ulceration by any means. It is rather, very often, one of recurrent episodes of duodenal bulb inflammation, with or without ulceration, but always with spasm and usually pain, and intermittent cicatrization of the duodenal bulb. The condition is associated with an anxious over-conscientious make-up and worry, which sets up through the vagus a hypersecretion of gastric acid. This is corrected by vagotomy, but in the process, the gastric motility is compromised, and this, together with any stenosis at the pylorus, will inevitably lead to gastric stasis, unless pyloroplasty is undertaken. Moreover I believe it is important to divide the pyloric sphincter and the longitudinal muscle of the duodenum and the pyloric canal to abolish the possibility of spasm in this area.

2. Gastric Ulcer. This series is a small one (I4 cases), but, as far as I am aware, no such series has been published before. At first, the supposition was that these chronic gastric ulcers were secondary to stasis gastritis, following duodenal scarring (Johnston, 1955) and it was considered that if the primary disease was corrected by vagotomy and pyloroplasty, the secondary lesion would heal. This proved true. Cases were then encountered where no duodenal abnormality was present, and the same operative procedure was $\frac{\overrightarrow{0}}{\mathcal{O}}$ carried out empirically, and, as will be seen from 2 the results, all these ulcers have also healed radio- $\frac{3}{\Phi}$ logically. All the cases have remained healed, $\stackrel{\square}{c}$ and some have been radiologically healed for two to four years. I would, therefore, merely conclude $\overrightarrow{\overrightarrow{\vec{S}}}$ that, in my experience, simple gastric ulceration $\overline{0}$ will heal, following the operation of vagotomy and $\frac{C}{0}$ Finney pyloroplasty. Details of this series are $\frac{\bar{c}}{\bar{c}}$ given in Table $\mathbf{I}$.

\section{Operative Technique}

Vagotomy is an operation of sight and touch. $\vec{\circ}$ For exposure of the anterior vagus and its branches, $\vec{\overrightarrow{ }}$ the stomach must be pulled firmly downwards, and the nerves tautened on the anterior surface of $\overline{8}$ the de-peritonealized cesophagus, when they can 3 . easily be felt. For exposure of the posterior nerve or nerves, the right index finger is passed behind the osophagus, and the trunk or trunks stretched $\mathrm{N}$ on the pulp of the finger, and hooked up to the $\vec{\omega}$ right side of the œsophagus. The Finney pyloro- ${ }_{\mathcal{V}}$ plasty has already been described.

\section{Post-operative Management}

No Ryle's tube is in situ and gastric suction is unnecessary. Intravenous fluids are not used $\stackrel{\bigcirc}{\partial}$ routinely. A restricted fluid regime is ordere $\vec{B}$ as follows: first post-operative day, $\mathrm{I} \mathrm{oz}$. wat hourly; second day, 2 oz. hourly; third day, 3 ot. hourly; fourth day, $4 \mathrm{oz}$. clear fluids hourly fifth day, nourishing fluids; sixth day, light diet. Any abdominal distension demands a slowing of this routine. The patients are usually out of bed $\frac{\circ}{\triangleright}$ on the first post-operative day, and progressive $\stackrel{\varrho}{\Rightarrow}$ ambulation is then encouraged. If an active chronic ulcer is present at the time of operation, reasonable bed rest is advised, and a strict gastric dietary regime is prescribed for three to four weeks until radiological healing is attained. A 을 third stage gastric dietary regime will then be followed for a further four weeks, and thereafter $\underline{3}$. a gradual return to normal diet. Otherwise $\delta$ normal diet can be resumed after about a fortnight.

\section{Mortality}

In this series of 118 cases, there have been two deaths, giving an operative mortality of $1.7 \%$. It is quite obviously a procedure technically easier o than gastrectomy, and should have a general $N$ mortality a good deal lower than this operation. N In considering this mortality, it seems reasonable 0 to note that this series includes all cases of emergency hæmorrhage, and that the average age $\frac{0}{\Phi}$ of the whole series is 50 years, a relatively high one $\stackrel{\infty}{?}$ due to a high percentage of the older age groups $T$ living in the suburban areas around this hospital. The details of the two deaths are as follows: 
TABLE I

\begin{tabular}{|c|c|c|c|c|c|c|}
\hline No. & Sex & Age & $\begin{array}{l}\text { Length of History } \\
\text { Pre-operative Barium Meal } \\
\text { (B.M.) }\end{array}$ & Operative Findings & $\begin{array}{c}\text { Post-operative } \\
\text { Barium Meal }\end{array}$ & $\begin{array}{c}\text { Follow-up } \\
\text { (years) } \\
\text { Visick } \\
\text { Classification }\end{array}$ \\
\hline $\mathbf{I}$ & M. & 52 & $\begin{array}{l}\text { I I years } \\
\text { B.M. positive, Dec. I } 956 \\
\text { positive, July I } 957\end{array}$ & $\begin{array}{l}\text { Op., Jan. I956 } \\
\text { Bleeding L.C.U. }\end{array}$ & Negative, Oct. I 957 & $\begin{array}{l}4+\text { years } \\
\text { Grade I }\end{array}$ \\
\hline 2 & M. & 54 & 13 years & Op., July r 957 & Negative, Feb. 1960 & $\begin{array}{l}2 \frac{1}{2} \text { years } \\
\text { Grade I }\end{array}$ \\
\hline 3 & M. & 70 & $\begin{array}{l}\text { I I years } \\
\text { B.M. positive, Dec. I } 956 \\
\text { positive, July I } 957\end{array}$ & $\begin{array}{l}\text { Op., Oct. } 1957 \\
\text { Small L.C.U. } \\
\text { Duodenum normal }\end{array}$ & Negative, Nov. 1957 & $\begin{array}{l}2+\text { years } \\
\text { Grade I }\end{array}$ \\
\hline 4 & M. & 52 & $\begin{array}{l}\text { I } 5 \text { years } \\
\text { B.M. positive, Sept. } 1957\end{array}$ & $\begin{array}{l}\text { Op., Oct. I } 957 \\
\text { Large L.C.U. } \\
\text { Duodenum normal }\end{array}$ & $\begin{array}{l}\text { Negative, Apr. I } 958 \\
\text { Slight hourglass, but } \\
\text { no ulcer, July } 1959\end{array}$ & $\begin{array}{l}2+\text { years } \\
\text { Grade I }\end{array}$ \\
\hline 5 & M. & 77 & $\begin{array}{l}4 \text { years } \\
\text { B.M. positive, Mar. I } 956 \\
\text { positive, Dec. } 1957\end{array}$ & $\begin{array}{l}\text { Op., Dec. I957 } \\
\text { Small L.C.U. } \\
\text { Scarred duodenum }\end{array}$ & Negative, Mar. $195^{8}$ & $\begin{array}{l}2+\text { years } \\
\text { Grade I }\end{array}$ \\
\hline 6 & F. & 57 & $\begin{array}{l}6 \text { years } \\
\text { B.M. positive, July I } 957 \\
\text { positive, Nov. } 1957\end{array}$ & $\begin{array}{l}\text { Op., Dec. I } 957 \\
\text { L.C.U. } \\
\text { Scarred duodenum }\end{array}$ & $\begin{array}{l}\text { Positive, Jan. } 195^{8} \\
\text { Positive, Feb. 1958 } \\
\text { Negative, Feb. } 1960\end{array}$ & $\begin{array}{l}2+\text { years } \\
\text { Grade I }\end{array}$ \\
\hline 7 & F. & 57 & $\begin{array}{l}2 \text { years } \\
\text { B.M. positive, Jan. } 1956 \\
\text { positive, Jan. } 1958\end{array}$ & $\begin{array}{l}\text { Op., Feb. } 1958 \\
\text { Small L.C.U. } \\
\text { Duodenum normal }\end{array}$ & $\begin{array}{l}\text { Negative, May } 1958 \\
\text { Negative, Sept. } 1958 \\
\text { Negative, Mạr. } 1959\end{array}$ & $\begin{array}{l}\text { I } \frac{3}{4} \text { years } \\
\text { Grade I }\end{array}$ \\
\hline 8 & M. & 56 & $\begin{array}{l}20 \text { years } \\
\text { B.M. positive, Apr. } 195^{8}\end{array}$ & $\begin{array}{l}\text { Op., Apr. } 195^{8} \\
\text { Large L.C.U. } \\
\text { Duodenum normal }\end{array}$ & Negative, Nov. 1959 & $\begin{array}{l}\text { I } \frac{3}{4} \text { years } \\
\text { Grade I }\end{array}$ \\
\hline 9 & M. & 61 & $\begin{array}{l}3 \text { years } \\
\text { B.M. positive, Aug. } 1955 \\
\text { positive, Aug. 1 } 957 \\
\text { positive, July } 1958\end{array}$ & $\begin{array}{l}\text { Op., July } 195^{8} \\
\text { Small L.C.U. } \\
\text { Duodenum normal }\end{array}$ & $\begin{array}{l}\text { Negative, Nov. } 1958 \\
\text { Negative, Jan. 1960 }\end{array}$ & $\begin{array}{l}\text { I } \frac{1}{2} \text { years } \\
\text { Grade I }\end{array}$ \\
\hline 10 & M. & 64 & $\begin{array}{l}5 \text { years } \\
\text { B.M. positive, May } 1956 \\
\text { positive, Nov. } 1957 \\
\text { positive, Sept. } 1958\end{array}$ & $\begin{array}{l}\text { Op., Sept. } 195^{8} \\
\text { Large L.C.U. } \\
\text { Duodenum normal }\end{array}$ & $\begin{array}{l}\text { Slight hourglass de- } \\
\text { formity but no ulcer, } \\
\text { Feb. 1 } 960\end{array}$ & $\begin{array}{l}\text { I } \frac{1}{4} \text { years } \\
\text { Grade II }\end{array}$ \\
\hline I I & $\mathrm{F}$. & 65 & $\begin{array}{l}\text { Io years } \\
\text { B.M. positive, Aug. I } 958 \\
\text { positive, Sept. I } 958\end{array}$ & $\begin{array}{l}\text { Op., Oct. I } 95^{8} \\
\text { Large L.C.U. } \\
\text { Pyloric stenosis }\end{array}$ & Negative, Nov. 1958 & $\begin{array}{l}\text { I years } \\
\text { Grade I }\end{array}$ \\
\hline 12 & M. & 57 & $\begin{array}{l}\text { I } 2 \text { years } \\
\text { B.M. not done }\end{array}$ & $\begin{array}{l}\text { Op., Dec. I } 958 \\
\text { Bleeding L.C.U. } \\
\text { Duodenum normal }\end{array}$ & $\begin{array}{l}\text { Negative, Dec. I } 95^{8} \\
\text { Negative, Jan. 1960 }\end{array}$ & $\begin{array}{l}\text { I year } \\
\text { Grade I }\end{array}$ \\
\hline 13 & M. & 50 & $\begin{array}{l}\text { I } 2 \text { years } \\
\text { B.M. positive, Sept. I } 959\end{array}$ & $\begin{array}{l}\text { Op., Sept. I } 959 \\
\text { Large L.C.U. } \\
\text { Chronic D.U. } \\
\text { Pyloric stenosis }\end{array}$ & Negative, Oct. I959 & $\begin{array}{l}\frac{1}{4}+\text { year } \\
\text { Grade I }\end{array}$ \\
\hline 14 & F. & 75 & $\begin{array}{l}\text { No definite history } \\
\text { B.M. positive, Dec. } 1959\end{array}$ & $\begin{array}{l}\text { Op., Dec. r } 959 \\
\text { Bleeding L.C.U. } \\
\text { Duodenum normal }\end{array}$ & Negative, Jan. I960 & $\begin{array}{l}\text { Recent } \\
\text { Grade I }\end{array}$ \\
\hline
\end{tabular}


I. Male, 57 years. Large D.U. Died I4th postoperative day from pulmonary embolism from deep femoral thrombosis. Autopsy showed the pyloroplasty wound secure.

2. Male, 62 years. Chronic penetrating D.U. Died seventh post-operative day. Gastroenteritis and bronchopneumonia.

\section{The Completeness of the Vagotomy}

The long-term success or failure of this procedure will depend on a sufficient ablation of the vagus, and the absence of subsequent regeneration to give sufficient secretion of 'nervous' juice to cause further duodenal irritation. The proof of this can only be evident after a long-term follow-up and it is intended to carry this out on the present series with a medical colleague as an independent assessor, when a sufficient time has elapsed. As to the immediate completeness of the vagotomy, taking the criteria of Holt and Robinson, (I955) that any case with an acidity of less than $30 \mathrm{ml}$. hydrochloric acid after insulininduced hypoglycæmia to $50 \mathrm{mg}$./100 $\mathrm{ml}$. has a complete vagotomy, the following results emerge: $\left.\begin{array}{l}\text { No. of cases examined }=82 \\ \text { No. with complete vagotomy }=60\end{array}\right\}$ Success $=73 \%$

\section{Results}

I. Bilious Vomiting. The first point of importance is the complete absence of bilious vomiting in this series. This shows a striking advance in this important respect over the operation of gastro-jejunostomy and vagotomy, e.g. incidence $7 \%$ (Holt, 1956), incidence 6\% (Hindmarsh, 1957).

2. Temporary dysphagia. Incidence five cases in $114(4 \%)$. All these cases recovered completely within a period of eight weeks, and no recurrence, has been noted to date. It may well arise from an autonomic imbalance following the division of the vagus, leaving full play for the sympathetic influence on the lower end of the asophagus.

3. Diarrhoea. Incidence 16 cases in $114(14 \%)$. This symptom is usually troublesome from breakfast time to mid-day, and the patient passes frequent formed but loose stools. I would consider it the main drawback of any vagotomy operation. It is an inconvenient after-effect rather than a serious complication, but certainly one we should strive to avoid. Recently it has been suggested (Burge and Clarke, 1959), that if the branch of the posterior vagus to the coliac ganglion be preserved, this after-effect will be avoided. If these results are confirmed in a large series, it will be a great advance.

4. Body Weight. In this series no case has been a clinical nutritional problem. In $74 \%$ body weight has remained stationary or increased. In $15 \%$ of cases there has been minor weight loss, usually a few pounds. In this context, it should be noted that a proportion of cases of duodenal ulcer are over-weight from constant nibbling.

5. Recurrent Ulceration. Three cases in II $(2.5 \%)$. The details of these are as follows:

Case I: operation 1956; poor digestive result, anæmia; fæces, positive for occult blood; Barium meal positive. Case 2: operation 1956; died at home of gastric hæmorrhage, January 1958. This patient was an alcoholic, who did not give his operation a chance. Case 3: operation 1957; has developed a lesser-curve ulcer with escargot deformity due to inadequate drainage through the pyloroplasty. $\mathrm{He}$ is at present symptomless, and does not wish any further procedure.

\section{Follow-up}

The results are tabulated in Table 2 . It is not proposed to consider any case not followed for less than a year, and this leaves 92 cases for followup purposes. Each case has been followed by personal interview and graded according to Visick's classification as set out below.

Grade I: completely symptom-free; 68 of 92 cases $(74 \%)$. Grade II: slight symptoms causing no disability; 18 of $92(20 \%)$. Grade $I I I(s)$ : moderate symptoms relieved by care, but improved symptomatically and clinically by the operation (satisfactory); nil. Grade III(u): moderate symptoms not relieved by care, clinical result (unsatisfactory); 3 of $92(3 \%)$ Grade IV: not improved by operation; I of 92 ( $1 \%$ ).

It is gratifying to note that $94 \%$ of the series can be regarded as having a satisfactory result. The details of the three cases in Grade III(u) are as follows:

TABLE 2

\begin{tabular}{|c|c|c|c|c|c|c|c|}
\hline $\begin{array}{l}\text { Follow-up } \\
\text { in Years }\end{array}$ & $\begin{array}{l}\text { No. of } \\
\text { Cases }\end{array}$ & $\underset{\text { I }}{\text { Grade }}$ & $\begin{array}{c}\text { Grade } \\
\text { II }\end{array}$ & $\begin{array}{l}\text { Grade } \\
\text { III (s.) }\end{array}$ & $\begin{array}{l}\text { Grade } \\
\text { III (u.) }\end{array}$ & $\begin{array}{c}\text { Grade } \\
\text { IV }\end{array}$ & Died \\
\hline 4 years + & 7 & 6 & Nil & Nil & Nil & Nil & $\mathbf{I}$ \\
\hline 3 years + & I I & 7 & 2 & Nil & I & $\mathbf{I}$ & Nil \\
\hline 2 years + & 35 & 28 & 6 & Nil & $\mathbf{I}$ & Nil & Nil \\
\hline r year + & 39 & 27 & 10 & $\mathrm{Nil}$ & $\mathbf{I}$ & Nil & I \\
\hline Totals & 92 & 68 & I 8 & Nil & 3 & $\mathbf{I}$ & 2 \\
\hline
\end{tabular}


Case 1.-Male, 45 years. Operation 1956. Scarred duodenum following hæmatemesis; still has indefinite flatulent dyspepsia, fatigue, anæmia; fæces, positive for occult blood. Barium meal positive.

Case 2.-Female, 65 years. Operation i957. No definite D.U., but scarring around the duodenum from a previous laparotomy; has persistent discomfort in the epigastrium; fæces, positive for occult blood. $\mathrm{Hb} 84 \%$. Barium meal negative. Body weight increased.

Case 3.-Male, 33 years. Operation 1958. Old duodenal scar, but no active ulcer. A poor personality who complains of persistent epigastric pain and occasional vomiting. Body weight stationary. Full investigation reveals no organic lesion.

The one Grade IV case was a chronic alcoholic, who abused his stomach and finally died of gastric hæmorrhage 10 months after operation.

\section{Discussion}

No firm conclusions can be drawn concerning the late results of this operation; they need a further study with independent assessment, as already indicated. The one- to four-year results are encouraging, and the evidence from longer follow-up series using vagotomy and gastro- jejunostomy suggests that the figures do not materially alter after this time. It was considered desirable to publish this series at this stage, as no similar series can be found in the literature.

The treatment of chronic lesser curve ulcer by vagotomy and Finney pyloroplasty seems to be an innovation and it is encouraging to note that radiological healing has been attained in each case, and there are no unsatisfactory digestion results. In view of this, it seemed right that attention should be drawn to the possibilities of this method of treatment in cases of chronic gastric ulcer.

\section{Summary}

I. One-hundred and four cases of duodenal ulcer, treated by vagotomy and Finney pyloroplasty are presented.

2. Fourteen cases of chronic lesser curve ulcer, treated by the same method, are discussed.

3. The advantages of the operation, the operative technique and post-operative management are indicated.

\section{REFERENCES}

Burge, H., and Clark, P. A. (1959): Post-Vagotomy Diarrhœa, its Causes and Prevention, Brit. med. F., i.

HINDMARSH, F. D. (1957): Duodenal Ulcer, Lancet, i, II I 3 .

Holt, R. L. (1956): Discussion of Surgical Management of Uncomplicated Duodenal Ulcer, Proc. roy. Soc. Med., 49, 501 . , and Robinson, A. F. (1955): Treatment of Duodenal Ulcer by Vagoto:ny and Gastrojejunostomy, Brit. F. Surg., $42,494$.

Johnston, H. D. (1955): Special Significance of Concomitant Gastric and Duodenal Ulcer, Lancet, i, 266.

Weinberg, J. A., Stempien, S. J., Movins, H. J., and SAgradi, A. E. (1956): Vagotomy and Pyloroplasty in the Treatment of Duodenal Ulcer, Amer. F. Surg., 92, 202. 